\title{
Tıp Öğrencilerinin Öğrenme İklimi Algılarının; Akademik Özyeterlik, Hekimlik Mesleğine Yönelik Tutum ve Akademik Başarı Açısından İncelenmesi
}

\section{The Examination of Medical Students' Learning Climate Perceptions Regarding the Academical Self-Efficacy, Attitude towards Medicine Occupation and Academical Success}

\author{
Nilüfer Demiral Yılmaz', Münevver Yalçınkaya ${ }^{2}$ \\ ${ }^{1}$ Ege Üniversitesi Tıp Fakültesi Tıp Eğitimi Anabilim Dalı, İzmir \\ ${ }^{2}$ Ege Üniversitesi Eğitim Fakültesi Eğitim Bilimleri Anabilim Dalı, İzmir \\ Yazışma Adresi \\ Öğr. Gör. Dr. Nilüfer Demiral Yılmaz \\ Ege Üniversitesi Tıp Fakültesi Dekanlık Binası Tıp Eğitimi Anabilim Dalı, 35100 Bornova, İzmir \\ e-mail: nilufer.demiral@gmail.com
}

\begin{abstract}
Anahtar Sözcükler:
klinik eğitim, klinik

öğrenme iklimi, yapısal

eşitlik modeli
\end{abstract}

Keywords:

clinical training, clinical

learning climate, structural equation modeling

Gönderilme Tarihi

Submitted:15.08.2018

Kabul Tarihi

Accepted: 08.10.2018

\section{ÖZET:}

Giriş ve Amaç: $\mathrm{Bu}$ çalışmanın amac1, tıp öğrencilerinin klinik öğrenme iklimi algıları, akademik özyeterlik, hekimlik mesleğine yönelik tutum ve akademik başarı değişkenleri arasındaki ilişkiyi bütünleşik bir modelde test etmektir.

Gereç ve Yöntem: İlişkisel tarama modelinde olan bu çalışmada Ege Üniversitesi Tip Fakültesi klinik eğitim döneminde bulunan 748 öğrenciden veri toplanmıştır. Araştırmada veriler; 1. Akademik özyeterlik ölçeği, 2. Hekimlik mesleğine yönelik tutum ölçeği, 3. Klinik öğrenme iklimi ölçeği ile toplanmıştır. Çalışmada yapısal eşitlik modellemesi ve path analizi ile istatistiksel analizler yapılmıştır. Araştırmada verileri çözümlemek için, istatistik paket programı (SPSS 18.0) ile LISREL 8.54 programları kullanılmıştır.

Bulgular: Araştırmada elde edilen yapısal eşitlik denklemleri:

Akademik Başarı=0.51*Klinik Öğrenme İklimi Alg1S1 $+0,59 *$ Akademik Özyeterlik $(\mathrm{R} 2=0.27)$

Makale Künye Bilgisi: Yilmaz N.D., M, Yalçınkaya, M. (2018). Tıp Öğrencilerinin Öğrenme İklimi Algılarının; Akademik Özyeterlik, Hekimlik Mesleğine Yönelik Tutum ve Akademik Başarı Açısından İncelenmesi. TıpĔ̈itimi Dünyası, 53, 13-23. 
Klinik öğrenme iklimi algısı ve Akademik özyeterlik, Akademik başarıyı istatistiksel olarak anlamlı bir şekilde yordamaktadır. Bu iki değişken birlikte Akademik başarının \% 27'sini açıklamaktadır.

Hekimlik Mesleğine Yönelik Tutum=0.42*Akademik başarı $+0,51 *$ Klinik öğrenme iklimi alg1s1 (R2=0.14)

Klinik öğrenme iklimi algısı ve Akademik başarı, Hekimlik mesleğine yönelik tutumu istatistiksel olarak anlamlı bir şekilde yordamaktadır. $\mathrm{Bu}$ iki değişken birlikte Hekimlik Mesleğine Yönelik Tutumun \% 14'ünü açıklamaktadir.

Sonuç: Klinikte eğitimde, öğrencilerin klinik öğrenme iklimi algıları, hekimlik mesleğine yönelik tutumları, akademik özyeterlik algıları ve akademik başarılarının birbiriyle olan ilişkisi eğitimin etkililiğinde dolayısıyla nitelikli hekimlerin yetişmesinde anahtar rol oynamaktadır.

\section{ABSTRACT:}

Aim: The aim of this study is to investigate the relationship between the clinical learning climate, academic self-efficacy, attitudes towards the medical profession and academic achievement of the clinical training students in medical schools.

Material and Method: This study, which is a relational descriptive model, collected data from 748 students who were in the clinical training period of Ege University School of Medicine. In the study, data were collected with three scales; 1. Academic self-efficacy scale, 2. Attitude scale towards the medical profession, 3. Clinical learning climate scale. Structural equation modeling and Path analysis were used for statistical analysis. Statistical package program (SPSS 18.0) and LISREL 8.54 programs were used to analyze the data in the study.

Result: The structural equations determined in this study:

Academic Success $=0.51 *$ Clinical Learning Climate Perception $+0.59 *$ Academic SelfEfficacy $(R 2=0.27)$.

Clinical learning climate perception and academic self-efficacy perception predict academic success significantly. These two variables explain $27 \%$ of academic success.

Attitude towards Profession of Medicine $=0.42 *$ Academic Achievement + 0.51 *Clinical Learning Climate Perception (R2 $=0.14$ ).

Clinical learning climate perception and academic achievement predict attitudes towards profession of medicine significantly. These two variables explain $14 \%$ of the attitudes towards the profession of medicine.

Conclusion: Students' clinical learning climate perceptions, attitudes towards medical profession, academic self-efficacy perceptions and academic achievements during clinical training are important in qualified physicians, training.

*Bu çalışma, Ege Üniversitesi Sosyal Bilimler Enstitüsü Eğitim Yönetimi, Teftişi, Planlanması ve Ekonomisi Anabilim Dalı doktora programında “Tıp Öğrencilerinin Öğrenme İklimi Algılarının; Akademik Özyeterlik, Hekimlik Mesleğine Yönelik Tutum ve Akademik Başarı Açısından İncelenmesi” başlıklı tez olarak sunulmuştur.

\section{GİRIŞ}

T1p fakülteleri denildiğinde genellikle akla ilk gelen klinik eğitim dönemidir. Klinik eğitim dönemi, öğrencilerin hastalar ve sorunlarıyla karşılaşarak mesleksel bilgi, beceri ve tutum kazandıkları, öğrendiklerini uygulama firsatı buldukları tıp eğitiminin en önemli dönemidir. 
Klinikte eğitimin önemi; gerçek mesleki uygulama içinde gerçek sorunlara dayanması ve öğrenenleri bu yönüyle motive etmesi bununla birlikte öğrenenlerin mesleki düşünme, davranış ve tutum özellikleri gösteren eğiticileri gözlemleyebilmeleridir. Ancak en başta yarışan hasta bakımı ve eğitim hizmeti, kalabalık öğrenci grupları, hastane işleyişinin öğrenmeye uygun olmaması, eğiticilerin motivasyon düşüklüğü ve eğitim becerileri konusundaki zayıflığı, kaynak yetersizliği ve öğrenme ikliminin olumsuz olması gibi klinik eğitim ortamı ile ilişkili sorunlar yüzünden sıklıkla sorunlu geçen bir süreçtir (1).

Literatürde olumlu bir klinik eğitim ortamı için önem taşıyan etmenlerin; eğiticilerin niteliği, öğrenci-eğitici ilişkisi, eğiticilerin eğitim ve değerlendirme yaklaşımları, eğitim programının yapısı ve öğrenme iklimi olduğu belirtilmektedir (2-4). Birleşik Krallık Mezuniyet Sonrası Eğitim Komitesi [The UK Standing Committee on Postgraduate Medical Education (SCOPME, 1991)] ise, öğrenmeye destek olan bir öğrenme ikliminin, başarılı bir eğitim için kritik önem taşıdığını vurgulamaktadır (5).

\section{‘Öğrenme İklimi' öğrenme ortamında} öğrencilerin müfredatın farklı yönlerini nasıl algıladıklarını tanımlamak için kullanılır (6). Öğrenme iklimi, öğrenme ortamının tonu ve atmosferi anlamına gelmektedir (7). Genn (2001)'e göre, müfredatın ve öğrenme ortamının 'ruhu ve canı' olarak tanımlanmaktadır (8). Öğrenme ortamı algısının merkezinde öğrenme iklimi bulunmaktadır. İklim, başı başına öğrenme ortamı ile ilgili değildir, öğrencilerin öğrenme ortamına nasıl yanıt verdiği yani öğrenme ortamı algısı ile ilgilidir (7). Öğrenme iklimi, öğrenmeyi etkileyen tüm değişkenleri kapsamaktadır ve öğrencilerin davranışlarını etkilediği, onlar tarafından algılanan öğrenme ortamının kalitesi ve bunun temel alındığı ortak davranışlar bütünü olarak tanımlanmaktadır (8). Öğrenme iklimi öğrenci ve eğiticiler arası iletişimin niteliğini, öğrencilerin aktif bir şekilde öğrenme sürecine katılımını, akademik beklenti düzeyini, güvenli ve saygın bir atmosferi işaret etmektedir (9).

Klinik eğitim döneminde tıp öğrencilerden sadece konu alanı ile ilgili görevler değil profesyonel düşünme, profesyonel tutum ve davranışlar da beklenilmektedir (10). Bu nedenle öğrencilerin mesleklerine yönelik tutumları önem kazanmaktadır. Mesleki tutum, meslekî davranışların en güçlü belirleyicilerinden olmakla birlikte yaşantı ve deneyimler sonucunda oluşur, bireyin mesleği algılayış biçimi, davranışları üzerinde yönlendirici ya da dinamik bir etkiye sahiptir (11). Öğrencilerin konuya, eğiticiye, okula veya mesleğe ilişkin tutumlarının akademik başarıyı etkilediği kabul edilmektedir.

Tutumların yanı sıra öğrencilerin akademik özyeterlik algılarının da akademik başarıyı etkilediği bilinmektedir (12-13). Algılanan akademik özyeterlik, öğrencinin kendisinde akademik bir işi başarıyla tamamlayabileceğine ilişkin inancıdır (14). Akademik özyeterlik algısının öğrencilerin başarısı üzerinde büyük öneme sahip olmasına rağmen, üniversite öğrencilerinin eğitim yaşantılarını iyileştirme için eksik olan tarafın, özellikle öğrencilerin özyeterliklerinin artırılmasına ilişkin önlemlerin olduğu belirtilmektedir.

Öğrenme iklimini etkileyen faktörlerin ortaya çıkarılması büyük önem taşımaktadır. Mesleğe yönelik tutum, akademik özyeterlik algısı ve akademik başarı değişkenlerinin öğrenme 
iklimini etkilediği bilinmektedir. Öğrenme iklimi araştırmalarında değişik gruplardan veri toplanıp çok yönlü bir perspektifle değerlendirme yapılabileceği gibi farklı değişkenler arasındaki ilişkinin de incelenebileceği öngörülmektedir. Bu çalışmanın amacı tıp fakültesi klinik eğitim dönemi öğrencilerinin klinik öğrenme iklimi algıs1, hekimlik mesleğine yönelik tutum, akademik özyeterlik algısı ve akademik başarı değişkenleri arasındaki ilişkinin bütünleşik bir modelde test edilmesidir.

\section{Gereç ve Yöntem}

$\mathrm{Bu}$ araştırma; tıp fakültesi klinik eğitim döneminde bulunan ögrencilerden toplanan verilerle klinik öğrenme iklimi algıları, akademik özyeterlik algıları, hekimlik mesleğine yönelik tutum ve akademik başarıları arasındaki ilişkiyi açıklamak için kurulan hipotetik modeli test etmeye yönelik tasarlanmış ilişkisel tarama modelindedir.

\section{Evren ve Örneklem}

Araştırmanın evrenini Ege Üniversitesi Tıp Fakültesi'nde klinik eğitim döneminde bulunan 842 öğrenci oluşturmaktadır. Araştırmada örneklem seçiminde amaçsal örnekleme (purposive sampling) yöntemi kullanılmıştır. Amaçsal örnekleme, çalışmanın amacına bağlı olarak bilgi açısından zengin durumların seçilerek derinlemesine araştırma yapılmasına olanak tanır (15-16). Örnekleme, öğrencilerin üç hafta ve üzeri klinikte eğitim aldıkları anabilim dalları seçilmiş ve bu kliniklerde bulunan öğrencilerden veri toplanmıştır. Öğrencilerin üç hafta ve üzeri sürede klinikte eğitim aldıkları anabilim dallarının (stajların) örnekleme alınmasının nedeni; öğrenme iklimi olgusunun ancak belli bir zaman dilimi içerisinde kavranabileceğinden dolayıdır.

\section{Veri Toplama Araçları}

Araştırmada veriler üç farklı ölçme aracı ile toplanmıştır. Bu ölçme araçları; Klinik öğrenme iklimi ölçeği, Hekimlik mesleğine yönelik tutum ölçeği ve Akademik özyeterlik ölçeğidir. Aşağıda araştırmada veri toplanırken kullanılan ölçme araçlarının özellikleri açıklanmaktadır.

\section{Akademik Özyeterlik Ölçeği}

Akademik Özyeterlik Ölçeği, Jerusalem ve Schwarzer (1981) tarafindan geliştirilmiş ve tek boyut içeren ölçeğin Yılmaz ve ark. (2007) tarafindan Almanca'dan Türkçe'ye uyarlama çalışması yapılmıştır (17). Ölçek, akademik özyeterlik için anlamlı bir yapı gösteren yedi maddeden oluşmakta ve 4'lü ölçekleme (bana hiç uymuyor: 1 - bana tamamen uyuyor: 4) ile puanlanmaktadır. Türkçe'ye uyarlama çalışmasında orijinal ölçek 672 üniversite öğrencisine uygulanmış, geçerlik ve güvenirliği belirlenmiştir. Analiz sonuçlarına göre, orijinal ölçekte yedi olan madde sayısı Türkçe'ye uyarlanan ölçekte de korunmuş, Türkçe ölçeğin de orijinal ölçek gibi tek boyutlu olduğu tespit edilmiştir.

\section{Hekimlik Mesleğine Yönelik Tutum Ölçeği}

Araştırmada kullanılan diğer ölçme aracı, Batı ve Bümen (2006) tarafından geliştirilen Hekimlik Mesleğine Yönelik Tutum Ölçeği'dir (18). Ölçek, 12'si olumlu ve 12'si olumsuz olan toplam 24 maddeden oluşmakta ve 5'li Likert ölçeği (hiç katılmıyorum: 1 - tamamen katılıyorum: 5) ile puanlanmaktadır. Ölçeğin faktör analizinde; isteklilik, yardımcı olma ve mesleğe adanmışlık olmak üzere üç alt boyut tanımlanmaktadır.

\section{Klinik Öğrenme İklimi Ölçeği}

Araştırmada kullanılan son ölçme aracı ise Demiral Yılmaz (2010) tarafından geliştirilen Klinik Öğrenme İklimi Ölçeği'dir. Bu ölçek, 
36 maddeden oluşmaktadır (19). Ölçeğin puanlaması 5'li Likert ölçeği (hiç katılmıyorum: 1 - tamamen katılıyorum: 5) ile yapılmaktadır. Ölçeğin faktör analizinde üç boyut tanımlanmaktadır. Bu boyutlar; klinik ortam, duygusal iklim ve motivasyon'dur.

$\mathrm{Bu}$ araştırmada öğrencilerin akademik başarıları, öğrencilerin veri toplama araçlarını doldurdukları döneme kadar olan genel akademik not ortalamalarını ifade etmektedir.

Araştırmada veri toplama araçları öğrencilere araştırmacı tarafindan dağıtılmış ve öğrencilere çalışma ile ilgili bilgilendirme yapılmıştır. Veriler, araştırmaya katılım konusunda gönüllü olan öğrencilerden tek oturumda, kendileri tarafindan doldurarak (self-reported) toplanmıştır.

\section{Verilerin Analizi}

Araştırmada temel olarak iki istatistiksel analiz yöntemi kullanılmıştır. Bunlardan ilki, Yapısal Eşitlik Modeli (YEM) diğeri ise Path Analizi'dir (20). Yapısal eşitlik modeli ile regresyon modelindeki değiş̧enler arasındaki yordayıcı yapısal ilişkiyle, faktör analizindeki gizil faktör yapılarını kapsamlı bir analizde birleştirmek amaçlanmaktadır. İlişskisel yöntem çözümlemesi olan Path analizi ile de klinik öğrenme iklimi, akademik özyeterlik, hekimlik mesleğine yönelik tutum ve akademik başarı arasındaki ilişkileri belirlemek için bir model oluşturulmuştur. Klinik öğrenme iklimini etkileyen yapıların bir model ile (klinik öğrenme iklimine etki ettiği düşünülen yapılar arasındaki ilişkiyi ortaya koyan bir yapısal eşitlik modeli) ortaya konulması önem taşımaktadır. Böyle bir model klinik öğrenme iklimine ilişkin bilinmeyen faktörlerin ortaya çıkarılmasını sağlayacaktır. Yapısal eşitlik modeli çalışmalarının en önemli özelliklerinden birisi; yapılan analizlerin gözlenemeyen yapıları gerçek nesneler ve olgular gibi ortaya koymasıdır. Araştırmada verileri çözümlemek için, istatistik paket programı (SPSS 18.0) ile LÍSREL 8.54 programları kullanılmıştır.

\section{Etik Kurul Onayı}

$\mathrm{Bu}$ araştırma Ege Üniversitesi Tip Fakültesi Araştırma Etik Kurulu tarafindan (Karar numarası: 11-6.1/10) onaylanmıştır. Araştırmaya katılan öğrencilerin gönüllü olurları yazılı ve sözlü olarak alınmıştır.

\section{Bulgular}

Araştırmaya 842 öğrenciden 748'i (\% 88,8) katılmıştır. Öğrencilerin cinsiyetlerine göre dağılımına bakıldığında, \% 42,2'sinin kadın, \%

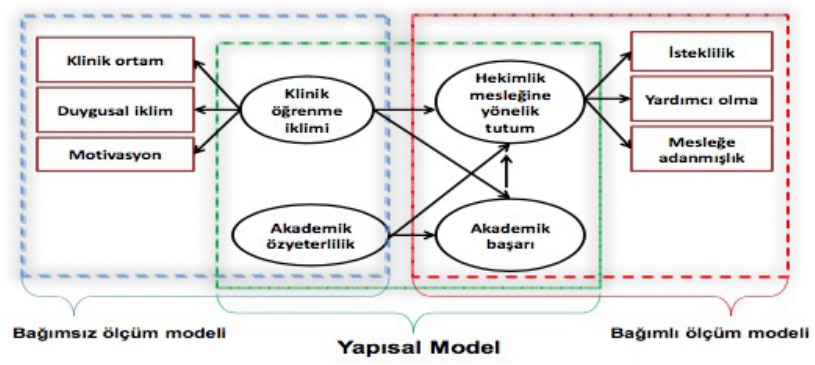

Şekil 1. Hipotez Model 
57,8'inin erkek olduğu görülmektedir.

Araştırmanın amacı doğrultusunda algılanan klinik öğrenme iklimi, akademik özyeterlik, hekimlik mesleğine yönelik tutum ile akademik başarı değişkenleri arasındaki ilişkiyi gösteren bir hipotez model kurulmuştur. Hipotez model Şekil 1'de verilmektedir. Hipotez modelde, iki ölçüm modeli ve bir yapısal model yer almaktadır. Ölçüm modellerinden biri bağımsız, diğeri de bağımlı ölçüm modelidir. Bağımsız ölçüm modelinde, Klinik öğrenme iklimi ve Akademik özyeterlik, hem gizil dışsal değişkenler hem bağımsız değişkenlerdir. Klinik ortam, duygusal iklim ve motivasyon ise, bağımsız gözlenen değişkenleridir. Modelde, klinik öğrenme iklimi değişkeninin klinik ortam, duygusal iklim ve motivasyon boyutları üzerindeki etkileri değerlendirilmektedir. Bağımlı ölçüm modelinde ise, Akademik başarı ve Hekimlik mesleğine yönelik tutum hem örtük içsel değişkenler hem de bağımlı değişkenlerdir. Bağımlı gözlenen değişkenler, isteklilik, yardımcı olma, mesleğe adanmışlık boyutlarıdır. Bu ölçüm modelinde de Hekimlik mesleğine yönelik tutum değişkeninin isteklilik, yardımcı olma, mesleğe adanmışlık boyutları üzerindeki etkileri incelenmektedir. Ayrıca yapısal modelde, bağımsız örtük değişkenler olan klinik öğrenme iklimi ve akademik özyeterlik ile bağımlı örtük değişkenler olan akademik başarı ve hekimlik mesleğine yönelik tutum arasındaki ilişkiler incelenmektedir.

Araştırmada veri analizi için, hipotetik yapısal

Tablo 1. Ölçme modeli için yapılan DFA sonuçları

\begin{tabular}{|l|c|c|c|c|c|c|}
\hline Model 1 & $\chi^{2}$ & GFI & AGFI & CFI & S-RMR & RMSEA \\
\hline Tek faktörlü yapı & $286,34_{(66) ;} \mathrm{p}=0,00$ & 0,95 & 0,92 & 0,98 & 0,043 & 0,067 \\
\hline
\end{tabular}

Analiz sonuçları incelendiğinde; $\chi 2=286,34$; örtük değişkenleri arasındaki ilişkiyi ortaya $\mathrm{Sd}=66 ; \quad \mathrm{p}=0,00 ; \quad \mathrm{GFI}=0,95 ; \quad \mathrm{AGFI}=0,92 ; \quad$ çıkarmaya yönelik hipotetik yapısal eşitlik $\mathrm{CFI}=0,98 ; \mathrm{S}-\mathrm{RMR}=0,043$ ve $\mathrm{RMSEA}=0,067$ modeline Path analizi uygulanmıştır. Modelde, olarak elde edilmiştir. Bu uyum iyiliği indeksleri klinik öğrenme iklimi ve akademik özyeterlik test edilen model için model-veri uyumunun sağlandığını göstermektedir.

Analizlerin bir sonraki aşamasında, klinik öğrenme iklimi, hekimlik mesleğine yönelik tutum, akademik özyeterlik ve akademik başarı değişkenleri bağımsız değişken olarak tanımlanırken, akademik başarı ve hekimlik mesleğine yönelik tutum değişkenleri bağıml değişken olarak modele dâhil edilmiştir. Hipotez model Şekil 2'de verilmektedir.

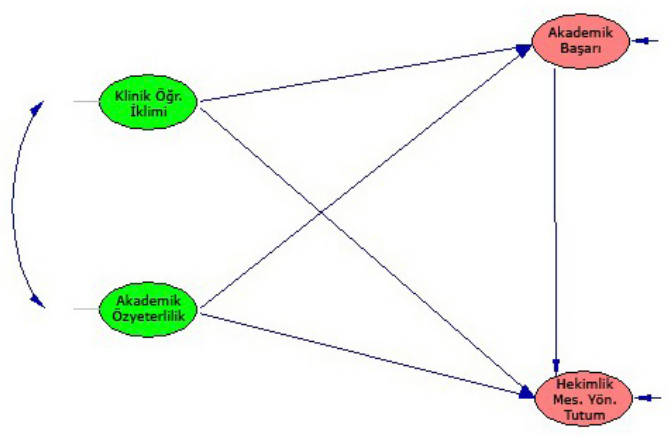

Şekil 2. Hipotez Model 
modelde yer alan örtük değişkenlerin (latent variables) kendi gözlenen değişkenleri ile ilişkilerini test eden bir ölçme modeli kurularak Doğrulayıcı faktör analizi (DFA) yapılmıştır. Ölçme modeli için yapılan DFA analizi sonucunda, test edilen modelin uyum iyiliği indeksleri Tablo 1'de verilmektedir.

Şekil 2'de görüldüğü gibi, klinik öğrenme iklimi alg1sı ile akademik başarı arasında doğrudan bir ilişki kurulurken, aynı değişken ile hekimlik mesleğine yönelik tutum arasında da doğrudan bir ilişki kurulmuştur. Ayrıca hipotez modele, klinik öğrenme iklimi algısı ile hekimlik mesleğine yönelik tutum arasında akademik başarının aracılık etkisini gösteren dolaylı bir ilişkide dâhil edilmiştir. Benzer şekilde, akademik özyeterlik ile akademik başarı ve hekimlik mesleğine yönelik tutum arasında doğrudan ilişki kurulurken, akademik özyeterlik ile hekimlik mesleğine yönelik tutum arasında akademik başarının aracılık etkisini gösteren dolaylı bir ilişki modele dâhil edilmiştir. Kurulan bu hipotez model test edilmiş ve Tablo 2'de yer alan sonuçlar elde edilmiştir.

Tablo 2. Modele ilişkin uyum iyiliği indeksleri

\begin{tabular}{|c|c|c|c|c|c|c|}
\hline$\chi^{2}$ & sd & $\chi^{2} /$ sd & GFI & AGFI & RMSEA & S-RMR \\
\hline 757,52 & 70 & 10,82 & 0,87 & 0,81 & 0,11 & 0,064 \\
\hline
\end{tabular}

Modelin uyum iyiliği indeksleri incelendiğinde, indekslerin ilgili literatüre göre iyi bir modelde istenilen değerlerin çok altında oldukları saptanmıştır. Şekil 2 incelendiğinde, Akademik özyeterlik ile Hekimlik mesleğine yönelik tutum arasında kurulan doğrudan ilişkinin istatistikî olarak anlamlı olmadığ1 gözlenmiş $(\mathrm{t}=1,28$; $\mathrm{p}>0,05)$ ve bağımlı örtük değişkenler olan Akademik başarı ile Hekimlik mesleğine yönelik tutum arasındaki ilişkinin de istatistiki olarak anlamlı olmadığı bulunmuştur $(\mathrm{t}=0,18 ; \mathrm{p}>0,05)$. $\mathrm{Bu}$ path katsayılarının istatistiksel olarak anlamlı olmamasından dolayı aynı değişkenler ile alternatif bir model kurulmuştur. Bu yeni modelde, yukarıda açıklanan ve istatistiki olarak anlamlı bulunmayan path'ler çıkarılmıştır. Alternatif modelin analizi sonucunda belirlenen model-veri uyumu indeksleri Tablo 3'de verilmektedir.

Tablo 3. Alternatif modele ilişkin uyum iyiliği indeksleri

\begin{tabular}{|c|c|c|c|c|c|c|}
\hline$\chi^{\mathbf{2}}$ & $\mathbf{s d}$ & $\boldsymbol{\chi}^{\mathbf{2} / \mathbf{s d}}$ & GFI & AGFI & RMSEA & S-RMR \\
\hline 333,20 & 67 & 4,97 & 0,94 & 0,91 & 0,073 & 0,043 \\
\hline
\end{tabular}

Analiz sonucunda, alternatif modele ait tüm uyum iyiliği indeks değerlerinin oldukça yüksek olduğu bulunmuştur. Birinci model ile ikinci modelin ki-kare değerleri ile serbestlik dereceleri arasındaki fark alınıp elde edilen değer ilgili serbestlik derecesinde $\chi^{2}$ tablo değeri ile karşılaştırıldığında $(\Delta \chi 2(67)=$ 424,32) elde edilen bu fark değerinin $p<0,001$ düzeyinde anlamlı olduğu belirlenmiştir. Kikare değerindeki iyileşme ve diğer uyum indekslerindeki artışlar alternatif modelin birinci modele göre değişkenler arasındaki ilişkileri daha iyi açıklayan bir yapısal eşitlik modeli olduğu saptanmıştır. Modellere ait bu karşılaştırma Tablo 4'te sunulmaktadır.

Tablo 4. Hiyerarşik modellerin karşılaştırması

\begin{tabular}{lccccccc}
\hline Model & $\chi^{2}$ & $\chi^{2} / \mathbf{s d}$ & GFI & AGFI & RMSEA & S-RMR & $\Delta \chi^{2}$ \\
\hline Hipotez & $757.52_{(70)}$ & 10,82 & 0.87 & 0.81 & 0.011 & 0.064 & - \\
Alternatif & $323.30_{(67)}$ & 4,97 & 0.94 & 0.91 & 0.073 & 0.043 & $424.2_{(3)}^{* * * *}$
\end{tabular}


Şekil 3. Alternatif modele ait path diyagramı

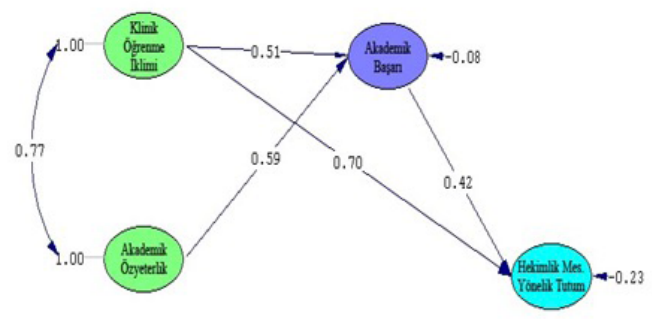

Chi- square $=335.31$, df $=67$, p-value $=0.00000$, RMSEA $=0.073$

Analiz sonuçlarına göre, bağımsız değişkenler Klinik öğrenme iklimi alg1sı ve Akademik özyeterlik algısı arasındaki ilişkinin $\mathrm{r}=0,77$ olduğu belirlenmiştir. $\mathrm{Bu}$ ilişki katsayısı istatistiki olarak anlamlıdır. Örtük değişkenler arasinda alternatif model tarafindan tahminlenen doğrudan ve dolaylı ilişkiler ise Tablo 5' de sunulmaktadir.

Tablo 5. Örtük değişkenler arasında Alternatif model tarafindan tahminllenen doğrudan ve dolaylı ilişkiler

\begin{tabular}{lcccccc}
\hline \multirow{2}{*}{ Değişkenler } & \multicolumn{2}{c}{ Akademik Başarı } & \multicolumn{2}{c}{$\begin{array}{c}\text { Hekimlik Mesleğine } \\
\text { Yönelik Tutum }\end{array}$} \\
\cline { 2 - 7 } & Doğrudan & Dolaylı & Toplam & Doğrudan & Dolayh & Toplam \\
\hline Klinik Öğrenme İklimi & 0,51 & - & 0,51 & 0,70 & 0,21 & 0,91 \\
\hline Akademik Özveterlik & 0,59 & - & 0,59 & - & 0,24 & 0,24 \\
\hline Akademik Basarı & - & - & - & 0,42 & - & 0,42 \\
\hline
\end{tabular}

Araştırmadan elde edilen bulgular sonucunda, klinik dönemde bulunan tıp öğrencileri için yapısal eşitlik denklemi aşağıdadır:

Akademik Başarı $=0.51 *$ Klinik öğrenme iklimi alg1s1 $+0,59 *$ Akademik özyeterlik algis1 $\mathrm{R} 2=0.27$

Araştırmadan elde edilen Yapısal eşitlik denkleminde yer alan değişkenlerin katsayılarına bakılarak, tıp öğrencileri için teorisi kurulan modelde Klinik öğrenme iklimi algısı ve Akademik özyeterlik algısının, Akademik başarıyı istatistiksel olarak anlamlı bir şekilde yordadığı görülmüş̧ür. Bu iki değişken birlikte Akademik başarının \% 27'sini açıklamaktadır.
Hekimlik mesleğine yönelik tutum $=$

$0.42 *$ Akademik başarı $+0,51 *$ Klinik öğrenme iklimi alg1s1 $\mathrm{R} 2=0.14$

$\mathrm{Bu}$ denklemde yer alan değişkenlerin katsayılarına bakılarak ise, tıp öğrencileri için teorisi kurulan modelde Klinik öğrenme iklimi algısı ve Akademik başarının, Hekimlik mesleğine yönelik tutumu istatistiksel olarak anlamlı bir şekilde yordadığ bulunmuştur. $\mathrm{Bu}$ iki değişken birlikte Hekimlik mesleğine yönelik tutumun \% 14'ünü açıklamaktadır. Ayrıca Akademik özyeterlik algısının, Hekimlik mesleğine yönelik tutuma dolaylı bir etkisi olduğu da görülmektedir. 


\section{Tartışma}

$\mathrm{Bu}$ araştırmada, tıp öğrencilerinin klinik öğrenme iklimi algıları, akademik özyeterlik algıları, hekimlik mesleğine yönelik tutum ve akademik başarı değişkenleri arasındaki ilişki bütünleşik bir modelde incelenmiştir.

Araştırmadan elde edilen bulguya göre, akademik özyeterlik algısı ile hekimlik mesleğine yönelik tutum arasında kurulan doğrudan ilişkinin istatistikî olarak anlamlı olmadığı belirlenmiştir. Literatürde özyeterlik inancı ile tutum arasındaki ilişkiyi inceleyen birçok araştırma (21-23). bulunmaktadır. $\mathrm{Bu}$ araştırmaların bulgularına göre; özyeterlik inancı ile tutum arasında pozitif yönlü bir ilişki bulunmaktadır. Bizim araştırmamızdan elde edilen bulgu, bahsedilen araştırmaların bulguları ile farklılaşmaktadır. Ayrıca bağımlı örtük değişkenler olan akademik başarı ile hekimlik mesleğine yönelik tutum arasındaki ilişkinin de istatistikî olarak anlamlı olmadığı saptanmıştır. Literatürde tutum ve başarı ilişkisinde tutumun mu başarıyı yoksa başarının mı tutumu etkilediği konusunda farklı sonuçlar bulunmaktadır. Papanastasiou ve Zembylas (2002) tarafından yapılan çalışmada fen bilimine karşı olumlu tutumun öğrencilerin bu alandaki başarısını arttırdığ 1 , ancak başarının olumlu tutumu garantilemediği belirlenmiştir (24). Diğer bir çalışmada, tutumun başarıyı etkilediği ve başarının tutumu etkilediği iki farklı modeli test ettikten sonra tutumun başarıyı etkilediği sonucuna ulaşmıştır (25). Berkant ve Efendioğlu'nun (2010) yaptığı çalışmada ise öğrencilerin tutumları ile başarıları arasında ilişkinin olmadığ

Araştırmanın diğer bir bulgusuna göre, klinik dönem tıp öğrencilerinin klinik öğrenme iklimi algıları öğrencilerin akademik başarılarını etkilemektedir. Yapılan çalışmalarda da öğrenme iklimi ve akademik başarı arasında bir ilişki bulunmuştur (27-28). Bu bulgu, Freiberg (1999) tarafından söylenilen "iklim, öğrenmenin etkili bir elemanı olurken, başarıyı da beraberinde getirir" görüşü tarafından desteklenmekte ve klinik öğrenme ikliminin önemini vurgulamaktadır (29). Ayrıca klinik dönem tıp öğrencilerinin akademik özyeterlik algıları ile akademik başarıları arasında doğrudan bir ilişkinin olduğu da bulunmuştur. Araştırmamızın bu bulgusu, literatürde yer alan araştırmalarla benzerlik göstermektedir (30-32). Sözkonusu araştırmalarda öğrencilerin özyeterlik algıları ile akademik başarıları arasında anlamlı bir ilişki saptanmıştır.

Araştırmanın diğer bulgusuna göre, klinik öğrenme iklimi algısı ve akademik başarı öğrencilerin hekimlik mesleğine yönelik tutumlarını etkileyen değişkenlerdir. Olumlu klinik öğrenme iklimi algısı öğrencinin akademik başarısını artırmakla birlikte hekimlik mesleğine yönelik olumlu tutum geliştirmesini de sağlamaktadır. Bu bulguya göre, mezun olacak hekimlerin niteliğinin artmasında ve meslek yaşantılarında olumlu tutum sergilemelerinde klinik öğrenme ortamının dolayısıyla algıladığı öğrenme ikliminin etkisinin olduğunu unutmamak gerekir.

\section{Sonuç}

Sonuç olarak, klinikte eğitimin karmaşık bir yapıdan oluştuğu ve bu yapıyı etkileyen farklı bileşenlerin olduğu görülmektedir. Klinikte eğitimde öğrencilerin klinik öğrenme iklimi algıları, hekimlik mesleğine yönelik tutumları, akademik özyeterlik algıları ve akademik başarıları kendi başına eğitimin etkililiğinde dolayısıyla da nitelikli hekimlerin yetişmesinde anahtar rol oynarken bu değişkenlerin birbiriyle olan ilişkisinin ortaya konulması klinikte eğitime ilişkin önemli ipuçları sağlayacaktır. 


\section{KAYNAKLAR}

1. Spencer J. ABC of Learning and Teaching in Medicine: Learning and Teaching in the Clinical Environment. BMJ 2003; 326: 591-594.

2. Chan D.S.K. Validation of the Clinical Learning Enviroment Inventory. West Journal Nurse Research 2003; 25: 519-532.

3. Cross V, Hicks C, Parle J, Field S. Perceptions of the Learning Enviroment in Higher Specialist Training of Doctors: Implications for Recruitment and Retention. Medical Education 2006; 40: 121-128.

4. Boor K, Scheele F, Van der Vleuten CP, Scherpbier AJJA, Teunissen PW, Sijtsma K. Psychometric Properties of an Instrument to Measure the Clinical Learning Enviroment. Medical Education 2007; 41: 92-99.

5. Roff S, Mc Aleer S. What is Educational Climate? Medical Teacher 2001; 23 (4): 333334.

6. Genn JM. AMEE Medical Education Guide no.23 (part 2): Curriculum, environment, climate, quality and change in medical education - a unifying perspective. Medical Teacher 2001b; 23(5): 445 - 454.

7. Saito A, Sunell S, Rucker L, Wilson M, Sato Y, Cathcart G. Learning climate in dental hygiene education: a longitudinal case study of a Japanese and Canadian programme. Int J Dent Hygiene 2010; 8: 134-142.

8. Genn JM. AMEE Medical Education Guide No. 23 (Part 1): Curriculum, environment, climate, quality and change in medical education- a unifying perspective. Medical Teacher 2001a; 23(4): 337-344.

9. Cohen J. Social, emotional, ethical and academic education: Creating a climate for learning, participation in democracy and wellbeing. Harvard Educational Review 2006; 76 (2): 201-237.

10. Gordon J. Strategic Planning in Medical Education: Enhancing The Learning Environment For Students in Clinical Settings. Medical Education 2000; 34: 841-850.

11. Özkal N. Sosyal Bilgiler Dersine Yönelik Tutum Ölçeğinin Geliştirilmesi. Eğitim ve Bilim 2002; 2(124): 52-55.

12. Bandura A. Self-Efficacy: Toward a Unifying Theory of Behavioral Change. Psychological Review 1994; 84 (2): 191-215.

13. Pajares FM. Current Directions in SelfEfficacy Research. In M. Maehr ve P.R. Pintrich (Eds.), Advances in Motivation and Achievement. Greenwich, CT: JAI Press, 1997.

14. Zimmerman BJ. Self-Efficacy and Educational Development. Self-Efficacy in Changing Societie. New York: Cambridge University Press, 1995.

15. De Poy E, Gitlin LN. Introduction to Research Understanding and Applying Multiple Strategies. USA: Elsevier Press, 2004.

16. Büyüköztürk Ş, Çakmak EK, Akgün ÖE, Karadeniz Ş, Demirel F. Bilimsel Araştırma Yöntemleri. Ankara: Pegem Akademi, 2008.

17. Yılmaz M, Gürçay D, Ekici G. Akademik Özyeterlik Ölçeğinin Türkçe'ye Uyarlanması. Hacettepe Üniversitesi Eğitim Fakültesi Dergisi 2007; 33: 253-259.

18. Batı A.H, Bümen N. Hekimlik Mesleğine Yönelik Tutum Ölçeğinin Geliştirilmesi. Tıp Eğitimi Dünyası 2006; 23: 41-50. 
19. Demiral Yılmaz N. T1p Öğrencilerinin Öğrenme İklimi Algılarının; Akademik Özyeterlik, Hekimlik Mesleğine Yönelik Tutum ve Akademik Başarı Açısından İncelenmesi. Ege Üniversitesi Sosyal Bilimler Enstitüsü Eğitim Yönetimi, Teftişi, Planlanması ve Ekonomisi Anabilim Dalı doktora tezi. İzmir, 2010.

20. Jöreskog KG, Sörbom D. Lirsel 8: Structural Eguation Modeling With Simplis Command Language. Hillsdale, $\mathrm{Nj}$, Lawrence Erlbaum Associates, 1993.

21. Oğuz A, Topkaya N. Ortaöğretim Alan Öğretmenliği Öğrencilerinin Öğretmen Özyeterlik İnançları ile Öğretmenliğe İlişkin Tutumları. Akademik Bakış Uluslarası Hakemli Sosyal Bilimler E-Dergisi 2008; 14.

22. Yılmaz V. LISREL ile Yapısal Eşitlik Modelleri: Tüketici Şikayetlerine Uygulanması. Anadolu Üniversitesi Sosyal Bilimler Dergisi 2004; 4 (1): 77-90

23. Tschannen-Moran M, Woolfolk-Hoy A, Hoy W. Teacher Efficacy: It's Meaning and Measure. Review of Educational Research 1998; 68: 202248.

24. Papanastasiou, C. School, Teaching and Family Influence on Student Attitudes Toward Science: Based on TIMSS Data Cyprus. Studies in Educational Evaluation 2000; 28: 71-86.

25. Schibeci RA, Riley JP. Influence of Students' Background and Perceptions on Science Attitudes and Achievement. Journal of Research in Science Teaching 1986; 23: 177-187.

26. Berkant HG, Efendioğlu A. Sinıf Öğretmenliği Bölümü Öğrencilerinin Bilgisayarla İlgili Özyeterlik Algıları ve Bilgisayar Destekli Eğitim Yapmaya İlişkin Tutumları. 9. Ulusal Sınıf Öğretmenliği Eğitimi
Sempozyumu. Elazığg, 2010.

27. Erbe BM. Correlates of School Achievement in Chicago Elementary Schools. ERIC Database, http://eric.uoregon.edu, ED: 441832 , 03.11.2008, 2010.

28. Dunn RJ, Harris LG. Organizational Dimensions of Climate and The Impact on School Achievement. Journal of Instructional Psychology 1998; 25 (2): 100-114.

29. Freiberg HJ. Measuring School Climate: Let me Count the Ways. Educational Leadership 1998; 56 (1): 22-26.

30. Yabaş D, Altun S. Farklılaştırılmış Öğretim Tasarımının Öğrencilerin Özyeterlik Algıları, Bilişüstü Becerileri ve Akademik Başarılarına Etkisinin İncelenmesi. Hacettepe Üniversitesi Eğitim Fakültesi Dergisi 2009; 37: 201-214.

31. Doğan N, Barış F. Tutum, Değer ve Özyeterlik Değişkenlerinin TIMSS-1999 ve TIMSS-2007 Sinavlarında Öğrencilerin Matematik Başarılarını Yordama Düzeyleri. Eğitim ve Psikolojide Ölçme ve Değerlendirme Dergisi 2010; 1 (1): 44-50.

32. Uzun B. TIMMS-R Türkiye Örneklemininde Fen Başarısını Etkileyen Değişkenlerin Cinsiyetler Arası Değişmezliğinin Değerlendirilmesi. Ankara: Hacettepe Üniversitesi Sosyal Bilimler Enstitüsü Yayımlanmamış Yüksek Lisans Tezi, 2008. 